S. Kiyko

PJSC “Electrometallurgical works "Dniprospetsstal” named after A.M. Kuzmin, Zaporozhye

\title{
PREDICTIVE ADAPTATION METHODOLOGY FOR PORTFOLIO MANAGEMENT OF ENERGY SAVING PROJECTS AT METALLURGICAL ENTERPRISES
}

A methodology for managing portfolios of energy saving projects at metallurgical enterprises is proposed. It forms a paradigm of predictive adaptation based on interconnected adaptive systems for planning, monitoring and managing changes and allows for forecasting energy consumption for complex technological processes and production, as well as modeling and evaluating the quality of the fuel and energy balance, in conditions of limited resources and risks, to form and select energy saving projects for implementation, while coordinating the priorities of the business strategy and the energy efficiency strategy of the metallurgical enterprise. A multi-level model of energy consumption of a metallurgical enterprise has been developed, which makes it possible to assess the effectiveness of energy-saving projects selected for implementation, objectively assess the share of each energy resource in the total flow, determine the energy intensity of a separate production, workshop, and the entire enterprise, and adjust the strategic direction in energy management. Using the model, it is possible to solve a number of tasks, including assessing the rationality and efficiency of the existing energy consumption structure at the enterprise, predicting the expected levels of energy consumption when changing the technology, product range and quality, and comparing various technologies and equipment in terms of energy efficiency, optimal management of energy flows taking into account changes in production conditions. The basic requirements for the organization of a planning and management system for a portfolio of energy saving projects at a metallurgical enterprise are formulated. The block diagram of a computer system for planning and managing a portfolio of energy saving projects at PJSC "Dneprospetsstal" is presented. The developed system of energy saving processes should be built into the system of enterprise processes, correspond to the strategic goals of the enterprise and the characteristics of the production process. The scheme of energy costs planning process implemented at the enterprise was considered.

Keywords: metallurgical enterprise; portfolio of energy saving projects; energy efficiency; cost planning; energy resources.

\section{Introduction}

Formulation of the problem. Development of organizational management systems, management accounting mechanisms and elimination of energy losses are the main objectives of energy saving projects at metallurgical enterprises. The general goal of increasing energy efficiency at the enterprise is implemented on the basis of managing a portfolio of energy-saving projects aimed at performing the following tasks: optimizing the energy balance; minimization of energy consumption; optimization of energy efficiency, etc. The difficulty is that it is hardly possible to objectively assess the share of each energy resource in the total flow, to determine the energy intensity of a separate production, workshop, entire enterprise, etc. The problem of forecasting and planning energy consumption in metallurgical production is a complex multi-parameter problem that has a probabilistic component, and a causal relationship of energy consumption with each of the considered parameters is rather complicated and does not have an unambiguous formal description.

Literature review. The essence of the process of increasing the energy efficiency of production is to reduce the specific consumption of energy carriers for the production of products, to rationalize the modes of energy consumption, to change the structure of energy consumption, to increase the environmental efficiency of production [1-2]. The work [1] presents a system of models for predicting the energy consumption of a metallurgical enterprise based on taking into account the correlation and regression relationships of trends in indicators for the formation of a dynamic assessment of the balance quality while implementing the principle of observing economic interests and eliminating negative processes in future energy consumption.

The concept and problems of energy efficiency, as well as the links between specific management practices and energy efficiency at the enterprise level are covered in [2]. The paper [3] proposes a scientific and methodological approach to building an organizational and economic mechanism for managing the strategic development of a metallurgical enterprise, which is based on certain logical relationships between basic concepts (market, property, energy resources, technology, potential, strategy). The author proposes to form a functional structure of an energy management system, which consists of four interrelated blocks: energy management; energy development of a metallurgical enterprise; regulatory and methodological support of energy consumption management; management of intellectual assets.

Work [4] proposes an algorithm for forming an investment portfolio of energy-saving measures for a metallurgical enterprise based on energy management, which allows one to identify and rank possible measures 
according to their relevance and form an investment portfolio within the available investment fund. The same authors in [5] consider the structure of information technology for managing portfolios of energy saving projects at metallurgical enterprises. But the proposed solution allows only to optimize the portfolio of securities and to select a resource provider.

Work [6] is devoted to a discussion of the factors affecting energy efficiency and conservation decisions, and the most appropriate policy to promote them. Increasing the efficiency of industrial production, mainly through the introduction of resource and energy saving technologies, equipment and processes, has caused the need to adjust the priority areas of development of energyintensive industries, including metallurgical enterprises [7-8]. The work [9] presents conceptual provisions for managing project portfolios in an organization and formalizing the methodological foundations for creating a value-oriented portfolio of projects for the development of metallurgical enterprises. Project portfolio management involves both analyzing all projects of the organization separately, and analyzing the characteristics of the entire set of projects implemented in the organization of projects and form a balanced portfolio [10]. The formalization of the main stages and methods of forming a portfolio of projects for a metallurgical enterprise taking into account its sustainable development strategy are given in [11]. Another approach to ensuring sustainable development of metallurgical enterprises is proposed by the authors in [12]. It is proposed to consider the process of strategic planning of a metallurgical enterprise as a dynamic set of interrelated management processes.

In the work [13], the main problems of power consumption and energy saving management in metallurgical production are formulated, the problems of rationing, planning of energy consumption by control levels are considered. The authors have proposed a method for predicting energy consumption, based on the construction of regression models with the inclusion of the time factor. The solution to the problem of predicting power consumption based on multivariate regression and correlation analyzes is given in the works [14-15]. In [16], this mathematical formulation of the problem of optimal forecasting of gas consumption at a metallurgical enterprise according to technical and economic criteria is reduced to a specialized problem of nonlinear mathematical programming.

Recently, machine learning methods have become popular for building models for predicting energy consumption. A detailed overview of the current state of machine learning models that are used for the task of predicting energy consumption in enterprises is presented in the work [17].

In [18], the assessment and forecasting of power consumption in power systems is based on fuzzy regression analysis. The work [19] uses hybrid Petri nets for modeling and analysis of metallurgical processes. The dynamic material flow and real-time changes of each technological state in the metallurgical process are visually modeled using this model. In [20], it is proposed to use neural networks and deep learning, namely the LSTM model, to predict the energy consumption of metallurgy enterprises. In [21], a method is proposed for predicting power consumption at a metallurgical enterprise, taking into account the following components: energy consumption, where the equipment does not change during the entire forecast; energy consumption where the transition to modern technological equipment is planned; energy consumption with new equipment and technology.

The authors in [22] considered the theoretical and practical aspects of operational planning and power consumption management at an industrial enterprise. The possibilities of mathematical modeling and optimization of technological modes are presented. On the example of the sinter production of a large metallurgical plant, the calculations of the optimal-compromise regime were carried out. It is shown that as a result of solving the problem of coordination, the shift productivity of the sinter plant will increase, and the power consumption will decrease. In work [23], the authors consider the possibility of short-term forecasting of power consumption of power systems using artificial neural networks. A technique for choosing the optimal configuration of an artificial neural network using a genetic algorithm is proposed. In [24], the problem of modeling the production and consumption of electricity in hybrid energy systems is considered.

The purpose of the article. The analysis of existing research has shown the relevance and the need to improve the organizational mechanism of energy saving management at a metallurgical enterprise based on the process-design approach. Thus, the purpose of this article is to create and describe the features of introducing a methodology for managing portfolios of energy saving projects at metallurgical enterprises, taking into account strategic goals, limited resources and risks. To achieve this goal, it is required to develop a model for multilevel planning of energy consumption in the implementation of a portfolio of energy saving projects, to formulate the basic requirements for the organization of a system for planning and managing a portfolio of energy saving projects at a metallurgical enterprise, to describe the essence of the organizational mechanism for managing energy saving at a metallurgical enterprise.

\section{Statement of basic materials}

\section{Methodology for planning and managing a portfolio of energy saving projects at a metallurgical enterprise}

The concept of managing a portfolio of energysaving projects is based on several interconnected adaptive systems: planning and formation, monitoring and change management (Fig. 1). 


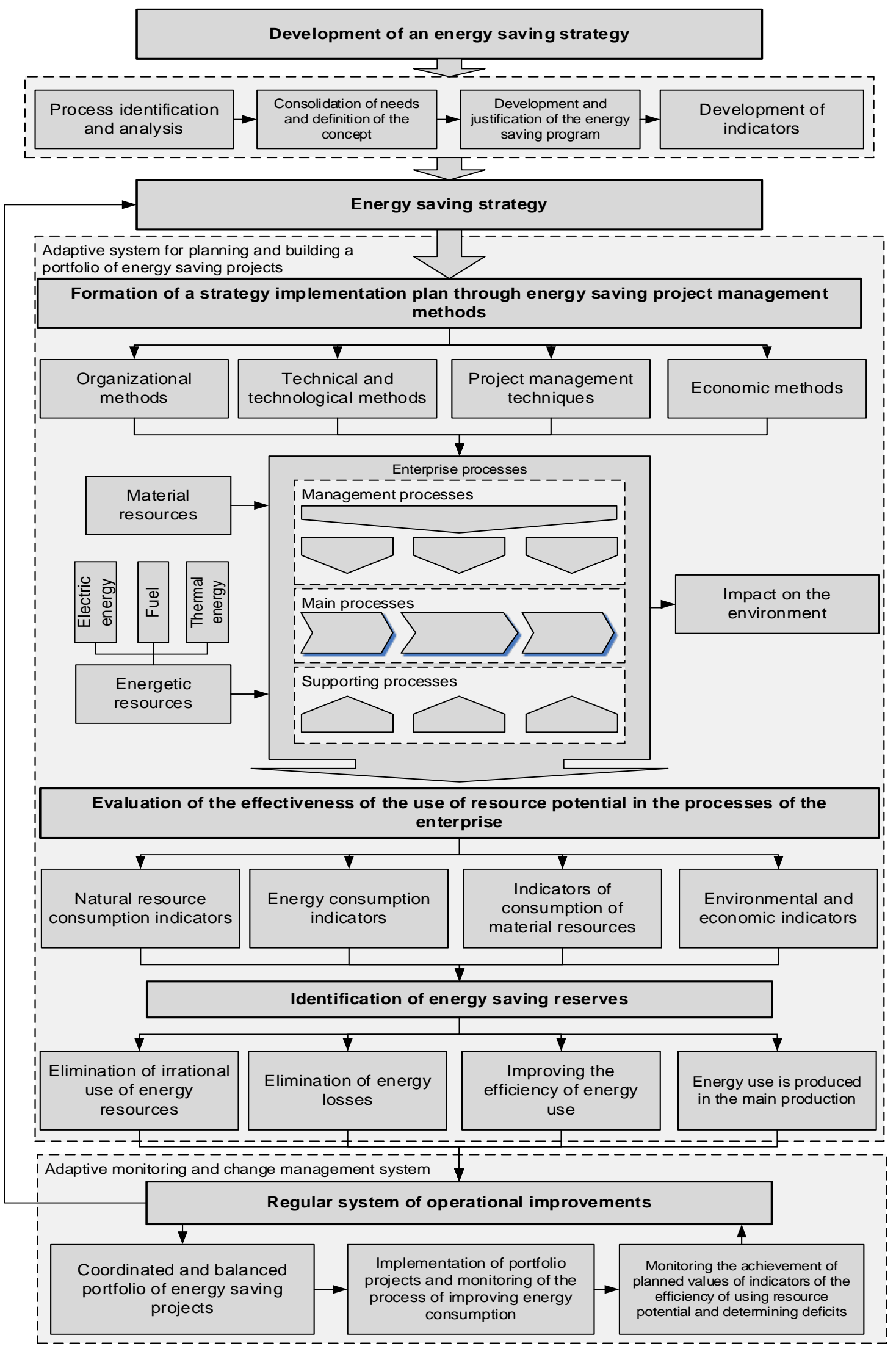

Fig. 1. Energy saving project portfolio management concept

Source: developed by the author.

The form of resolving the main contradiction between the process of implementing a portfolio of energy saving projects at a metallurgical enterprise and a tool for organizing energy-economic links between the processes of energy consumption and energy saving is the mechanism of predictive (predictive) adaptation in the 
integrated management of energy consumption of a metallurgical enterprise. First, it is predictive analytics of energy consumption and the quality of the fuel and energy balance. Secondly, it is the adaptive feedback block that monitors energy consumption and controls the achievement of the goals of the energy program and the goals of the implementation of energy saving projects selected in the portfolio is of great importance in the dynamic analysis and formation of the fuel and energy balance at a metallurgical enterprise. With the help of appropriate management decisions, this influences the formation of dynamic standards for the management of the energy consumption subsystem, the optimal construction of energy characteristics with a given accuracy according to the criterion of minimum technical and economic losses, to solve the problem of minimizing the total forecast error of energy resources, energy efficiency analysis, resource allocation for the program energy saving and adjusting the priorities of the energy strategy.

Thus, a flexible adaptive mechanism for optimizing energy assets is formed to maintain a high assessment of the quality of the fuel and energy balance of a metallurgical enterprise, which ensures the coordination of an effective energy strategy and a strategy for developing business processes. This allows to prepare management decisions when the corresponding indicator values and signals appear, by which you can notice early signs of the onset of important events in the energy situation and for making decisions on proactive energy management and implementation of energy saving projects.

A multilevel model for planning energy consumption of a metallurgical enterprise in the implementation of a portfolio of energy saving projects is shown in Fig. 2.

In a multilevel model for planning energy consumption of a metallurgical enterprise, three organizational levels can be distinguished (energy consumption at general production, general economic and technological levels) and two levels of time planning (monthly and daily planning).

\section{Computer system for planning and managing a portfolio of energy saving projects at a metallurgical enterprise}

To solve the problems of planning and managing a portfolio of energy saving projects, as well as energy management, "Dneprospetsstal" has implemented a number of automated systems (Fig. 3), the core being a corporate information management system based on SAP ERP (ECC 6.0). To obtain accurate and timely information on the supply and consumption of energy resources, several software and hardware complexes of metering systems are used, namely, an automated system for commercial metering of energy resources of an enterprise, an automated system for commercial metering of electricity, an automated system for technical metering of electricity (to ensure technical metering of electricity by consumers and by cost centers) and others.

The problem associated with the implementation of an effective mechanism for the use of energy balances for planning and managing energy consumption at the enterprise level is solved by introducing an automated cost accounting system and balancing the consumption of fuel and energy resources.

On the basis of the SAP ERP platform (ECC 6.0), an automated information system for managing the budgetary process was also created, the main purpose of which is to determine the total planned volume of energy consumption and form a plan for energy costs for a given period - a year, quarter, month. With the help of this system, the following tasks are solved: ensuring the consistency of actions of the divisions of the enterprise in terms of performing tasks related to calculating the volume of energy consumption and calculating the cost; improving the quality and optimization of the timing of planning energy costs; regulation of the process of planning energy costs.

The main critical factors for the success of the process are: availability of a reliable base of actual rates of energy consumption in the ERP-system and the availability of this information to the participants in the process; availability of reliable forecasted prices for energy resources, which take into account the price level in contracts concluded with their suppliers, as well as the conjuncture of market prices for energy resources. Energy consumption rates by product type are approved by the Ministry of Industrial Policy of Ukraine.

Energy saving activity is a process in the structure of enterprise processes related to energy consumption. The process approach allows you to coordinate energy saving activities with other enterprise processes (resources, goals, objectives, etc.). The implementation of individual energy saving projects also takes place within the framework of energy saving processes. It is advisable to form an organizational mechanism for energy saving management on the basis of a balanced combination and improvement of elements of the design and process approaches, using their main advantages in order to increase the efficiency of energy saving organization at metallurgical enterprises. At the same time, the project approach is used in the formation of a program and a portfolio of energy saving projects, solving problems of optimizing costs for the implementation of energy saving projects, in assessing energy efficiency and business results taking into account risk factors, etc. 


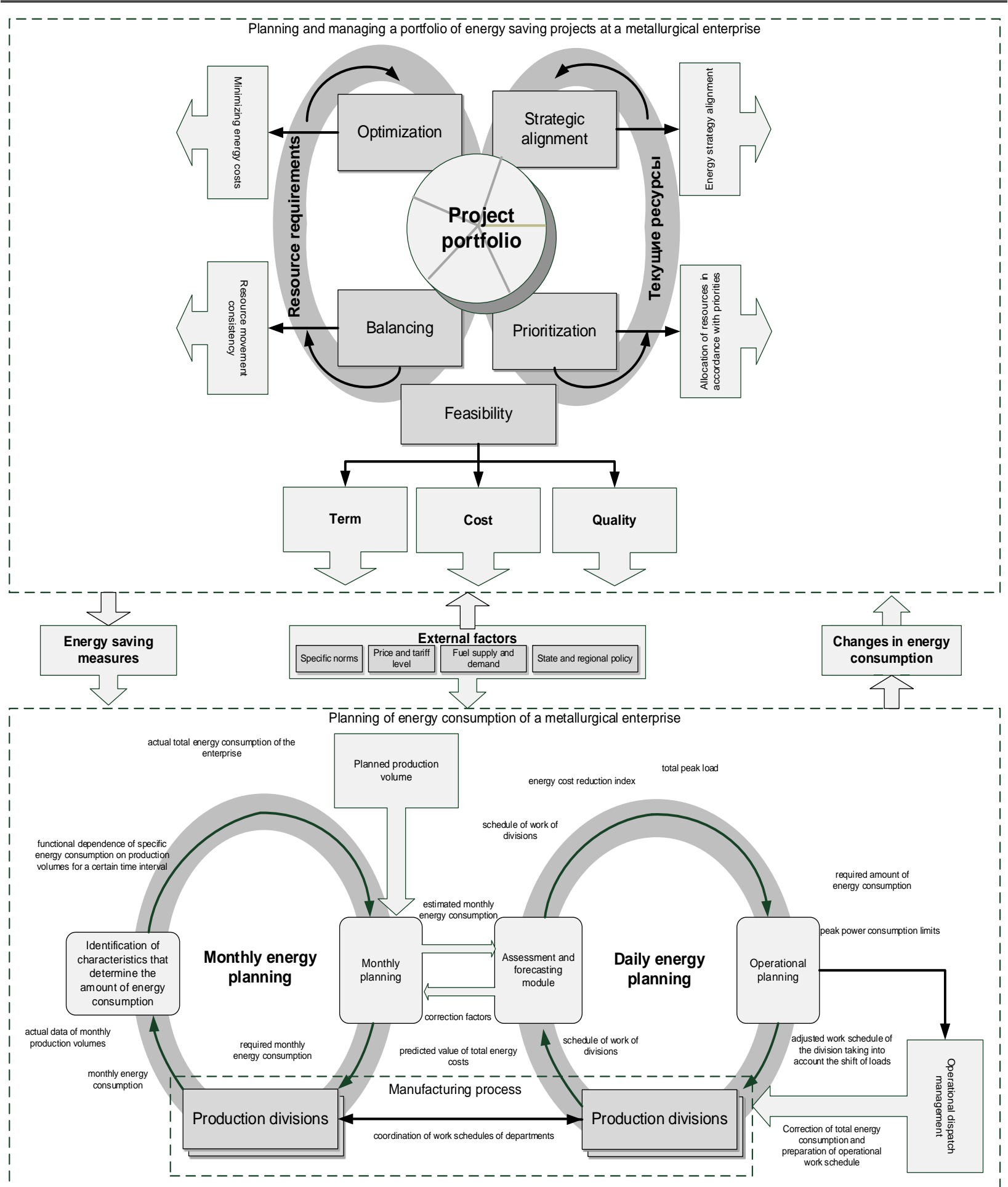

Fig. 2. Multilevel energy planning model for the implementation of a portfolio of energy saving projects

Source: developed by the author.

The process approach is used in the development of a general energy saving management scheme at a metallurgical enterprise. When used correctly, project and process management approaches complement and reinforce each other. Thus, the processes of energy saving should be integrated into the processes of the enterprise and coordinated with the financial, investment, organizational, production, motivational policies of the enterprise. These processes should not be carried out in isolation, but should be aimed at achieving the strategic goals of the enterprise in order to generate additional income based on improving energy efficiency. Energy saving processes are those that support the basic processes of the enterprise. The main activity of the enterprise is the production of metal products, the execution of works, and the provision of services. The main energy saving processes are: the analysis of energy consumption and energy saving, development, planning and implementation of energy saving projects, etc. The scheme for integrating energy saving processes into the system of enterprise business processes is shown in Fig. 4. 


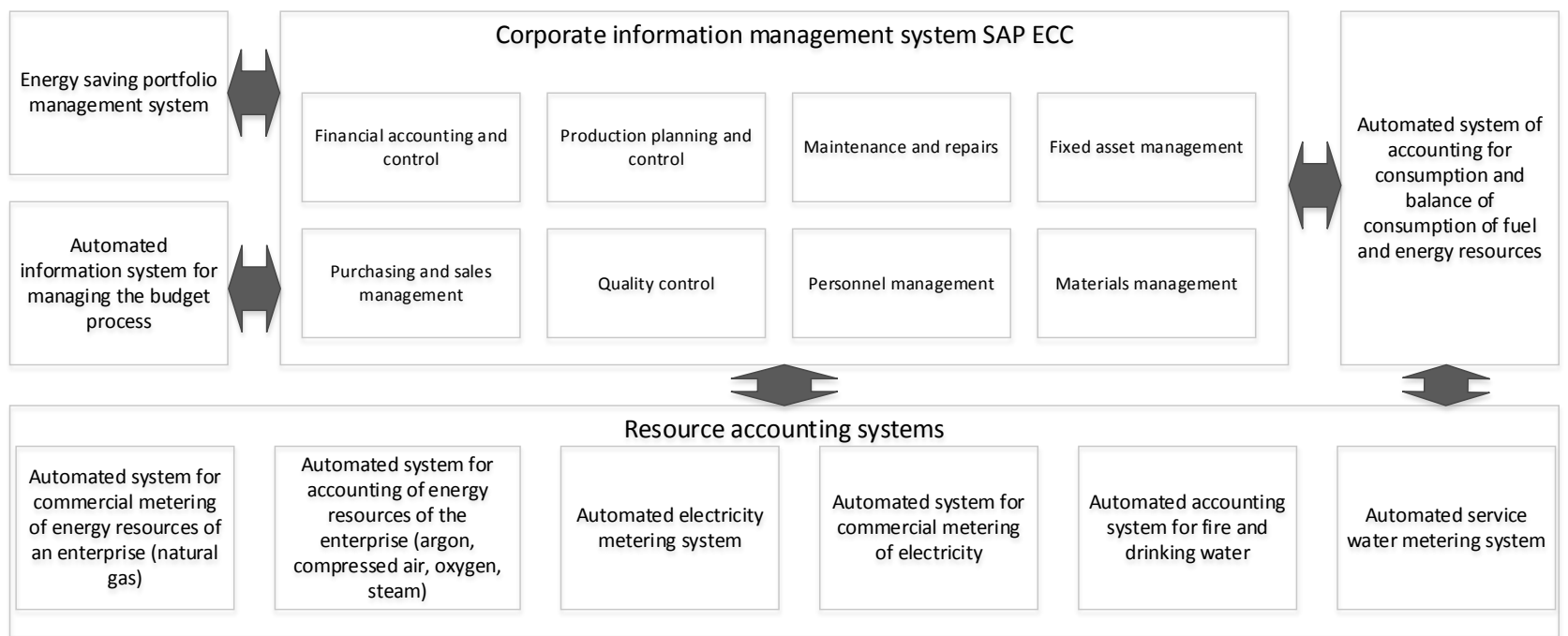

Fig. 3. The existing block diagram of a computer system for planning and managing a portfolio of energy saving projects at PJSC "Dneprospetsstal”

Source: developed by the author.

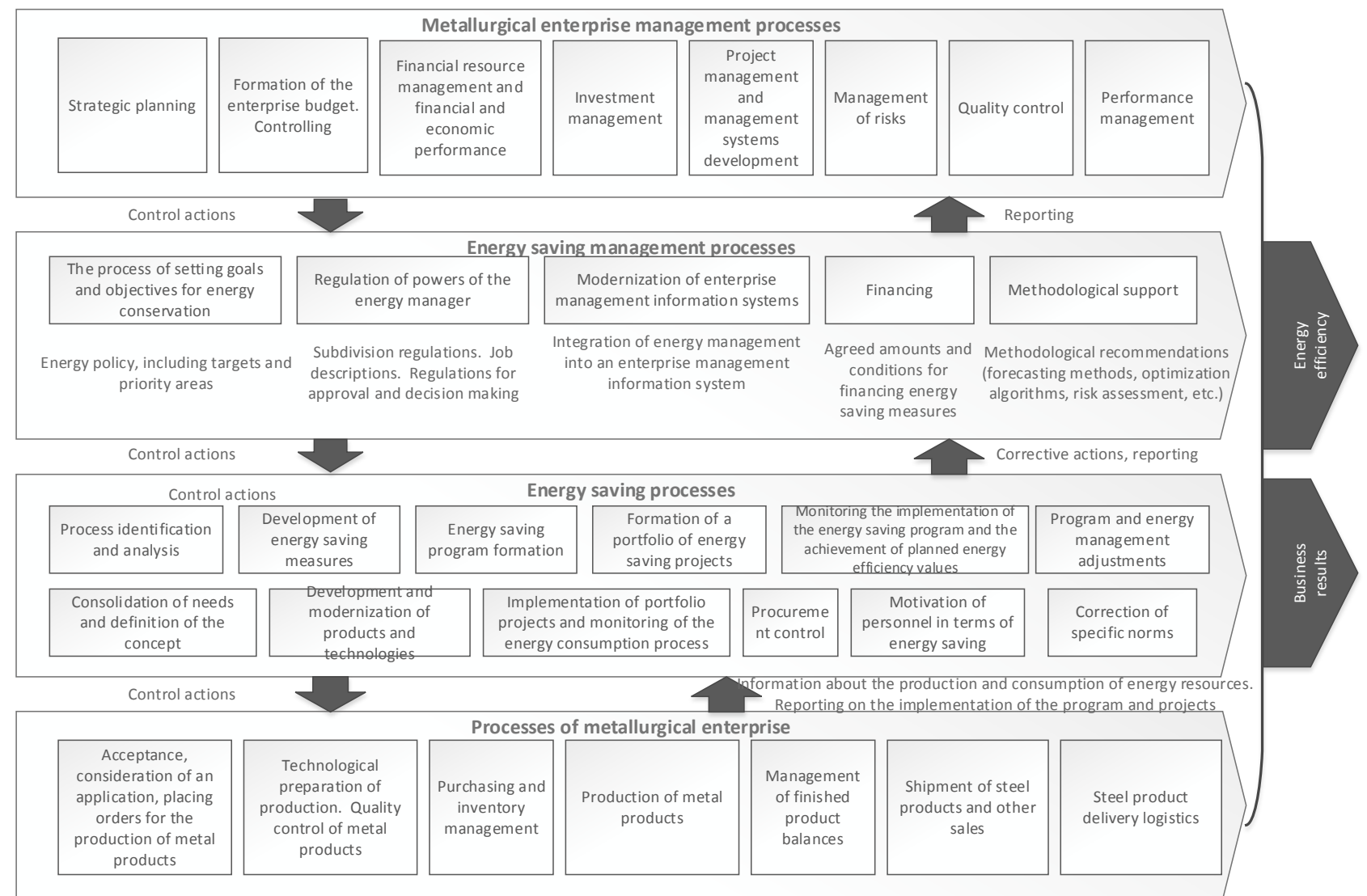

Fig. 4. Scheme of integration of energy saving processes into the system of business processes of a metallurgical enterprise

Source: developed by the author.

Energy saving processes share resources with other processes. These include financial resources (budget for energy saving projects), human resources (personnel performing work on the development and implementation of energy saving measures), material resources (equipment, materials, energy resources), information resources (corpo- rate management system, automated control systems and energy management, etc.).

\section{Energy cost planning process}

Let's take a closer look at the process of planning energy costs (Fig. 5). 


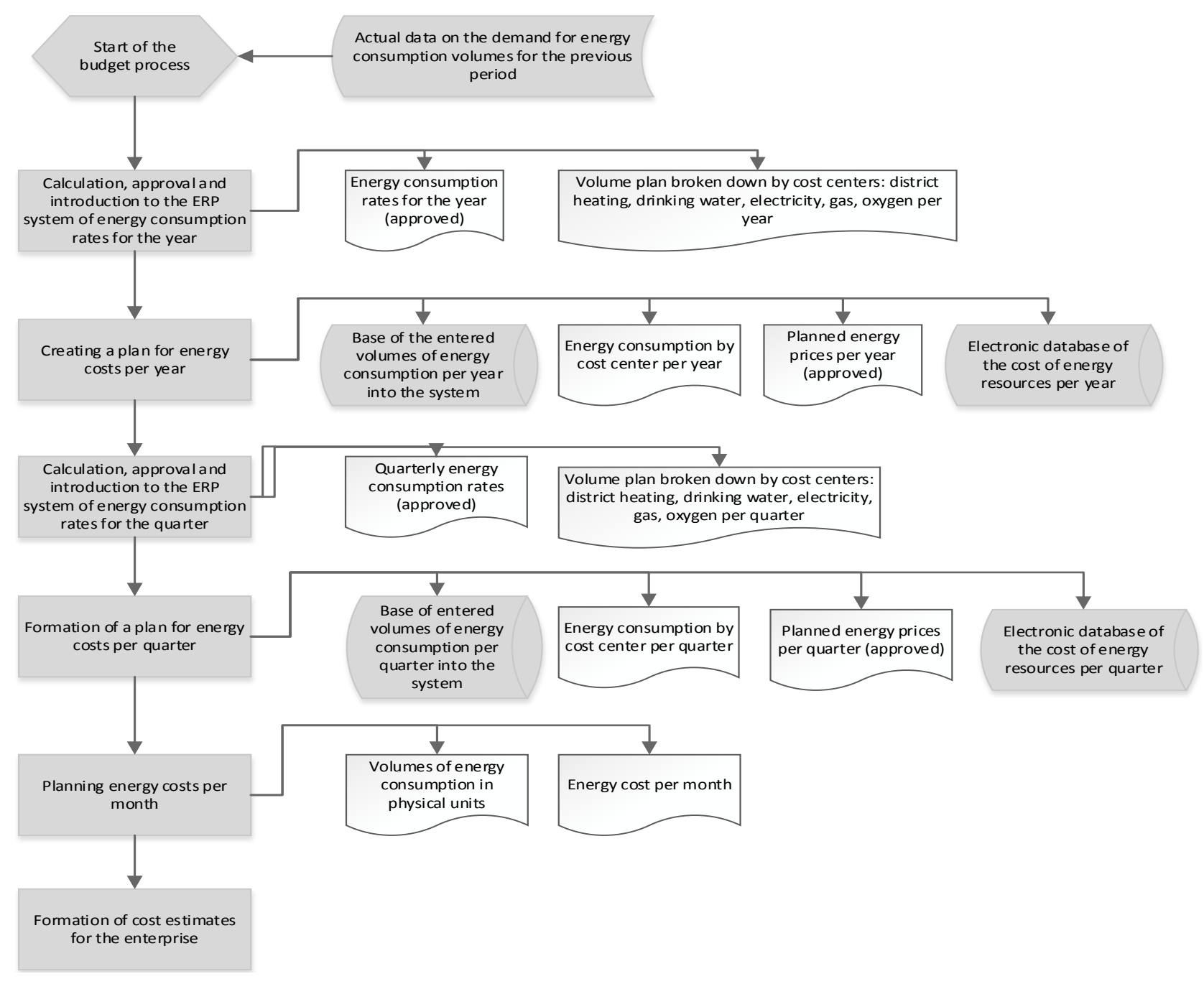

Fig. 5. Diagram of the energy cost planning process

Source: developed by the author.

The input to the process is the actual data on the demand for energy consumption in the previous period, as well as the approved cost plan by cost center (cost center).

The output (result) of the process are: agreed and approved rates of energy consumption for a year/quarter; electronic base of the cost of energy resources per month/quarter/year; base of entered volumes of energy consumption per month/quarter/year; energy consumption by cost center per year/quarter; planned prices for energy resources per month/quarter/year; volume plan by cost center: heating, natural gas, electricity, steam, oxygen monthly/quarterly/yearly.

The process itself consists of the following subprocesses: calculation, approval and introduction into the ERP-system of energy consumption rates per year; formation of a plan for energy costs per year; calculation, approval and introduction into the ERP-system of energy consumption rates per quarter; formation of a plan for energy costs per quarter; planning energy costs per month.

When developing the norms of the unit consumption of energy resources for the places where the costs of workshops arise, the following are taken into account: the dynamics of the actual unit consumption of energy resources for the previous periods; approved norms of energy carriers per year; introduction of new technologies, organizational and technical measures to save energy resources and new equipment as part of the implementation of energy saving projects; the degree of deterioration of the existing technological and power equipment, etc.

The constant part of the planned energy resources is determined by calculation according to: passport data of power equipment; the number of working workers in the shops; household and administrative areas; current sanitary standards, etc.

Based on the approved norms of energy consumption and planned production volumes using simulation modeling [25], the variable part of energy resources is 
determined for each cost center.

The results of the energy saving process are capital investments and organizational measures, a motivation system and corresponding job descriptions aimed at achieving energy savings and increasing production energy efficiency.

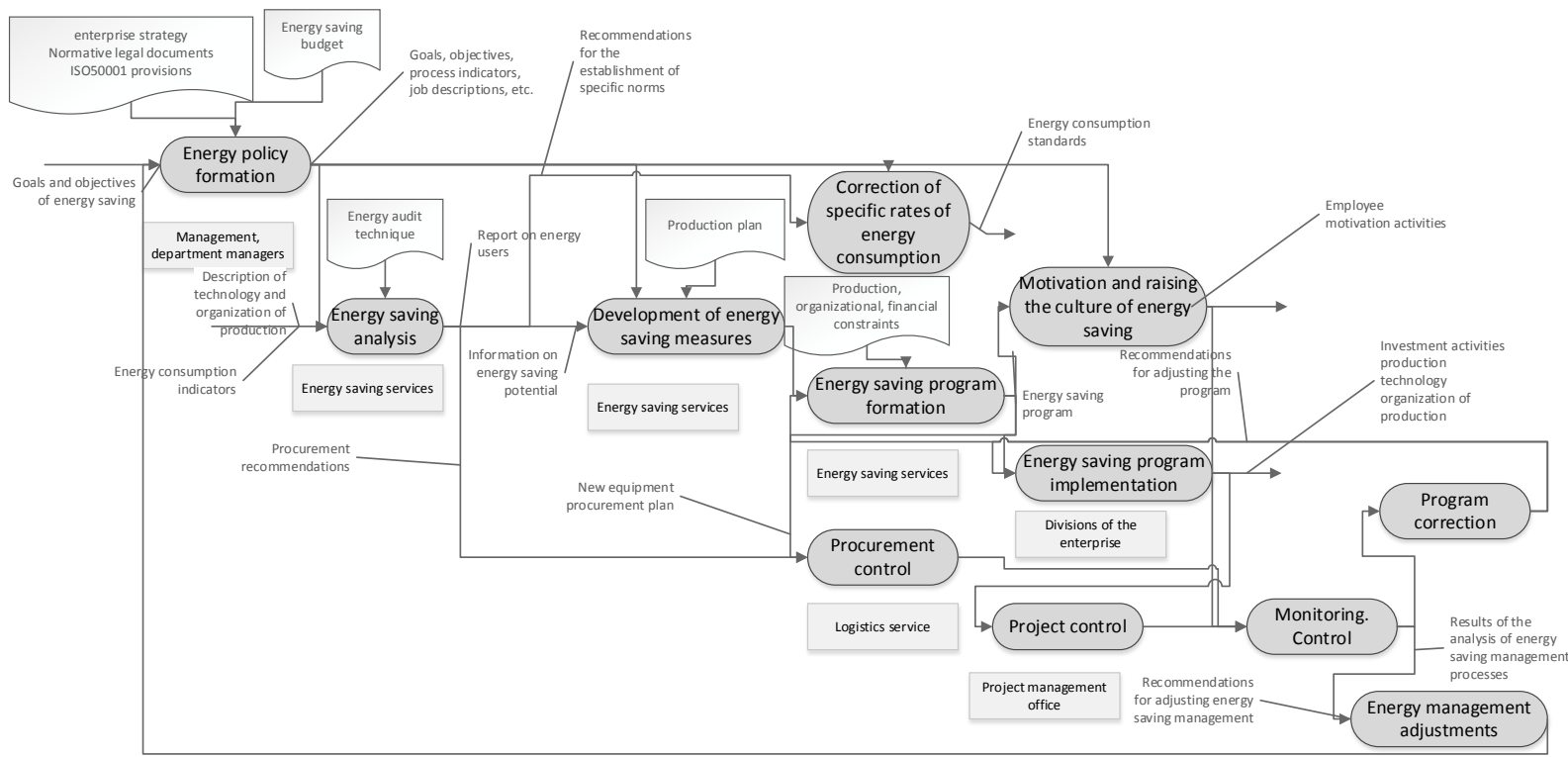

Fig. 6. Energy saving management organization diagram at a metallurgical enterprise Source: developed by the author.

With the help of the proposed approach and models, a portfolio of energy saving projects of PJSC Dneprospetsstal was formed, which included projects promising for implementation in accordance with the energy strategy. So, in the period from 2016 to 2018, the enterprise implemented energy saving projects, some of which are shown in Fig. 7-8.

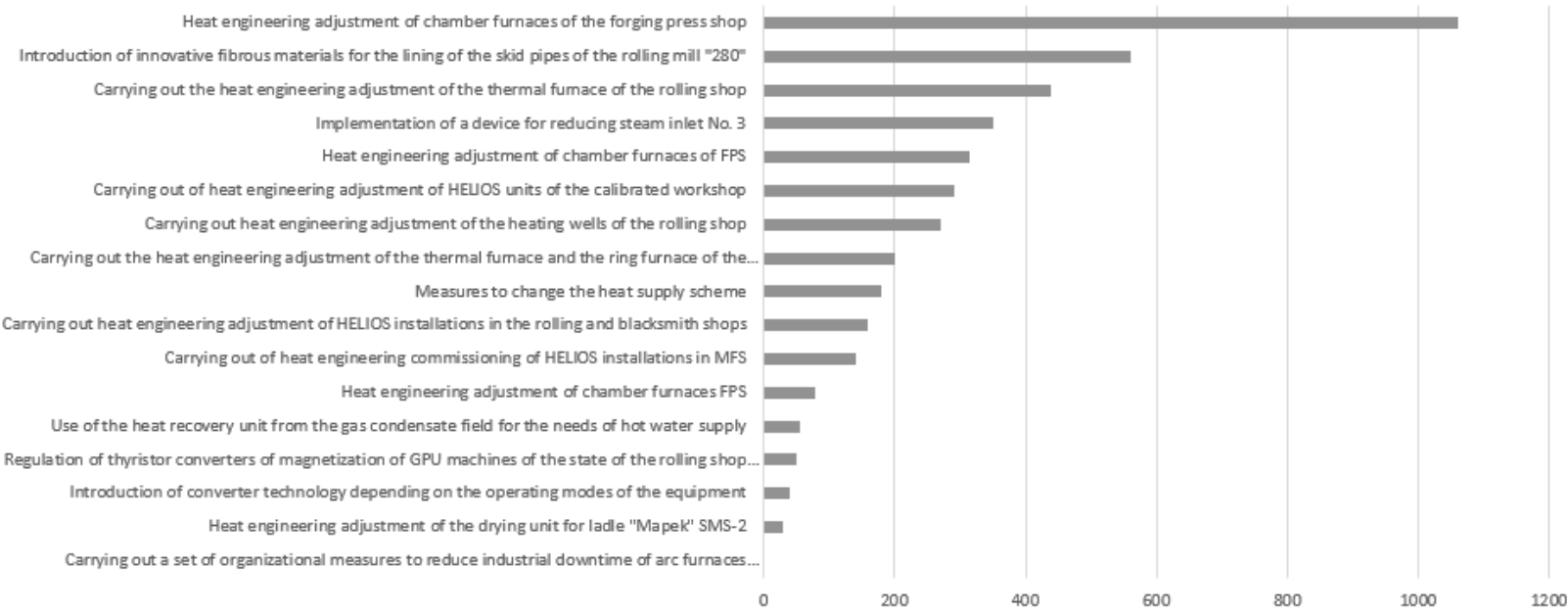

Fig. 7. Investments in energy saving at PJSC "Dneprospetsstal" (thousand UAH) Source: developed by the author. 
Cost of saved energy resources, thousand UAH

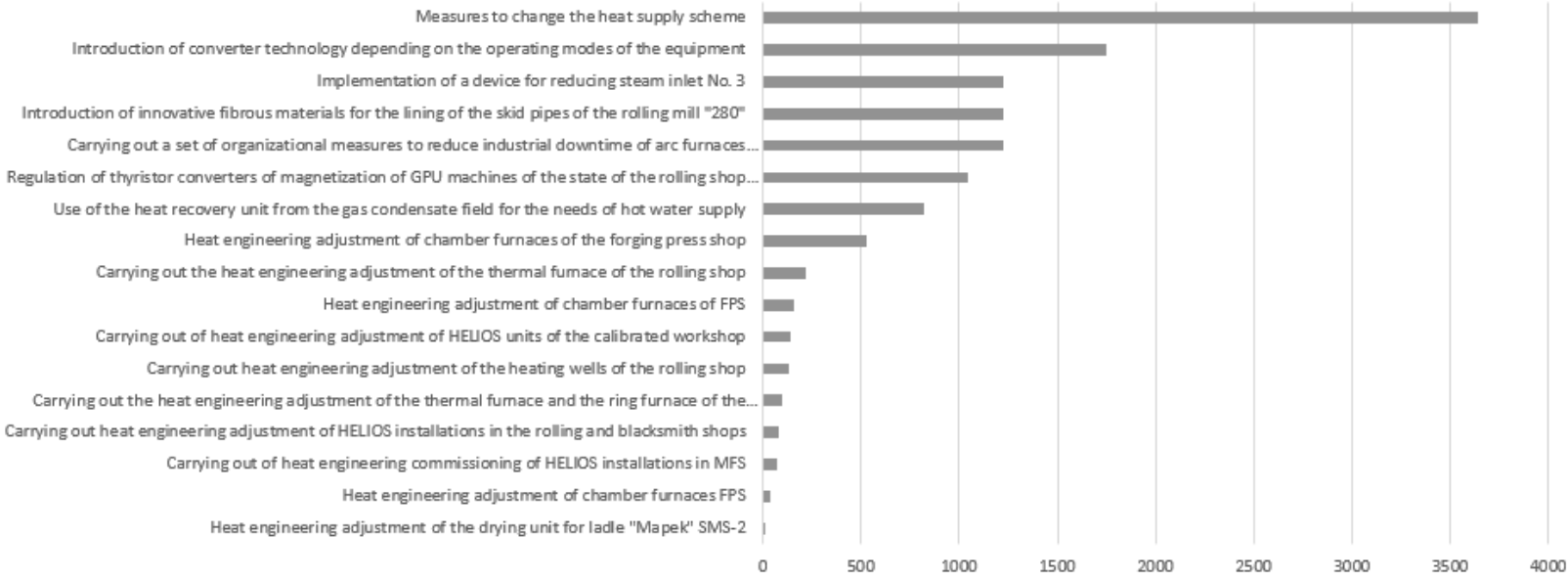

Fig. 8. The value of the annual saving of energy resources from the introduction of energy saving measures Source: developed by the author.

With the help of a simulation model [25], an assessment of the implementation of the target use of energy resources after the implementation of projects and measures for energy saving was carried out.

The analysis of the portfolio reveals that, in general, for Dneprospetsstal PrJSC, the largest share in energy savings is occupied by such a direction as attracting secondary energy resources (heat energy), which reflects the sectoral organizational and technological features of production and requires further improvement of existing technologies. At the second place there is such a direction as improving equipment and operating modes, rational use of fuel and energy resources and electricity, and only in third place in terms of energy saving is the introduction of energy-saving equipment.

As a fragment Fig. 9 shows a graph of the accumulated amounts of actual energy consumption for one of the months and the target energy consumption obtained as a result of the simulation.

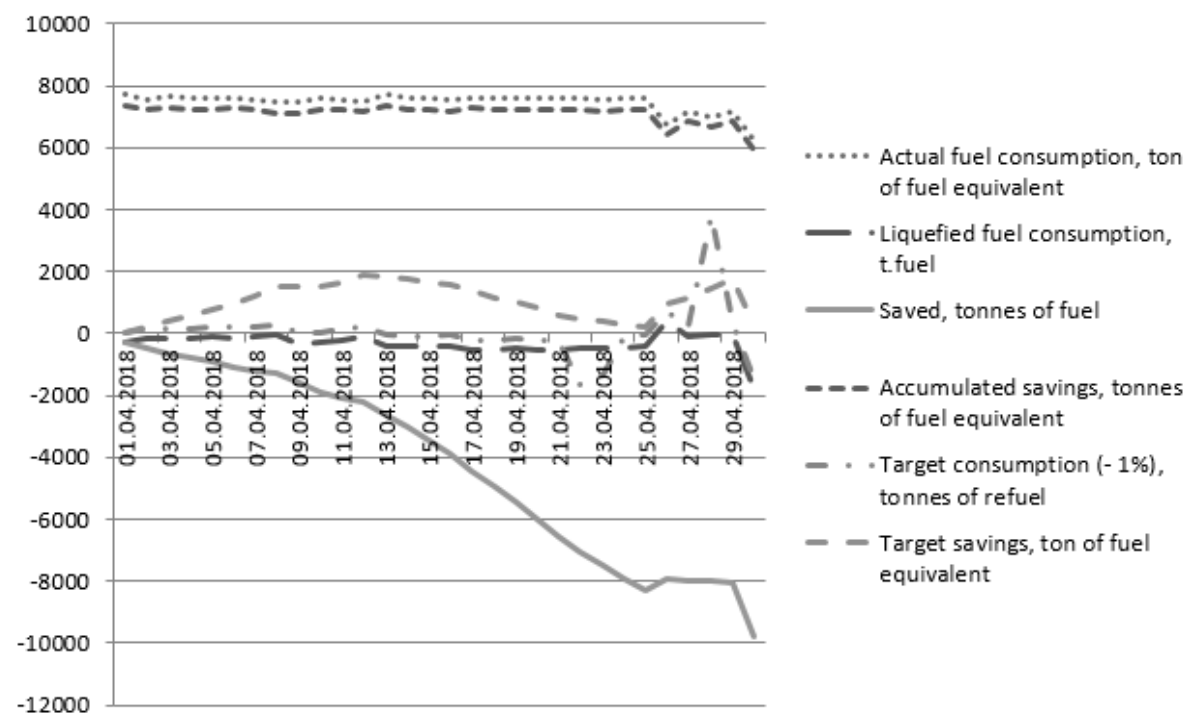

Fig. 9. Comparison of simulation results and actual fuel consumption Source: developed by the author.

As can be seen from the figure, the company has reduced fuel consumption as a result of energy saving measures. Despite the fact that the enterprise has not reached the target level of energy efficiency, the forecast error when modeling energy consumption for a metallurgical enterprise is at a satisfactory level.

Thus, as a result of the implementation of the en- ergy saving program and the introduction of organizational and technical measures, 340 thousand m3 of fuel and 1.6 million $\mathrm{kWh}$ of electricity were saved in 2018 . Due to the implementation of the energy saving program and the introduction of organizational and technical measures in 2019, 518 thousand $\mathrm{m} 3$ of fuel and 1.7 million kWh of electricity were saved. 


\section{Conclusions}

Thus, the paper proposes a methodology for managing portfolios of energy saving projects at metallurgical enterprises, which is characterized by the formation of a predictive adaptation paradigm based on interconnected adaptive systems of planning, monitoring and change management and allows, on the basis of forecasting energy consumption for complex technological processes and industries, as well as modeling and assessing the quality of the fuel and energy balance, in conditions of limited resources and risks, form and select for the implementation of energy saving projects while agreeing the priorities of the business strategy and the energy efficiency strategy of the metallurgical enterprise.

A multi-level model of energy consumption of a metallurgical enterprise has been developed, which makes it possible to assess the effectiveness of energysaving projects selected for implementation, objectively assess the share of each energy resource in the total flow, determine the energy intensity of a separate production, workshop, and the entire enterprise, and adjust the strategic direction in energy management.

The use of the developed model makes it possible to consistently analyze energy saving projects in order to identify the possibility of their implementation at the enterprise, coordinate project implementation plans and enterprise plans at various planning levels, select the most promising projects for implementation in accordance with an effective energy strategy.

A software and methodological complex for managing portfolios of energy saving projects at metallurgical enterprises has been developed, which includes a set of software, information, mathematical, organizational and methodological support for monitoring energy consumption and quality of the fuel and energy balance, planning and monitoring the implementation of projects and energy saving programs for metallurgical enterprise. Approbation of the developed models and computer tools at PJSC "Dneprospetsstal" showed that it is possible to effectively manage energy efficiency based on the management of programs and project portfolios. So, in the period from 2017 to 2019, the company implemented energy saving projects for a total amount of UAH 2,135 thousand. With the help of these projects and activities, it was planned and actually achieved a reduction in natural gas consumption by $1.5 \%(0.61$ thousand tons of conventional fuel), heat energy by $2 \%$. The cost of the saved energy resources amounted to UAH 5897.5 thousand.

\section{References}

1. Koksharov, V.A. (2015), Theoretical-methodological basis of formation of the enterprise strategy improving energy efficiency, European Science and Technology: materials of the X International research and practice conference, Vol. I. Publishing office Vela Verlag Waldkraiburg, Munich, Germany, pp. 143-148.

2. Martin, R., Muûls, M., De Preux, L.B. and Wagner, U.J. (2012), Anatomy of a paradox: Management practices, organizational structure and energy efficiency, Journal of Environmental Economics and Management, No. 63(2), pp. 208-223.

3. Lyzunova, O.M. (2017), "Mekhanizmy upravlinnya enerhetychnoyu skladovoyu v systemi zabezpechennya efektyvnosti metalurhiynykh pidpryyemstv" [Mechanisms of energy component management in the system of ensuring the efficiency of metallurgical enterprises: a monograph], Mariupol, 263 p.

4. Dubrovin, V.I. and Yus'kiv, O.I. (2019), "Upravlinnya portfelyamy proektiv enerhozberezhennya na metalurhiynykh pidpryyemstvakh” [Portfolio management of energy saving projects at metallurgical enterprises], Radio Electronics and Informatics, No. 2(85), pp. 43-46.

5. Dubrovin, V.I. and Yus'kiv, O.I. (2019), "Struktura informatsiynoyi tekhnolohiyi upravlinnya portfelyamy proektiv enerhozberezhennya na metalurhiynykh pidpryyemstvakh" [Structure of information technology of portfolio management of energy saving projects at metallurgical enterprises], Electrical and Power Engineering, No. 4, pp. 46-55.

6. Tsyutsyura, S.V. (2007), "Upravlinnya innovatsiynymy proektamy modernizatsiyi pidpryyemstv enerhoyemnykh haluzey" [Management of innovative projects of modernization of industrial enterprises of energy halls: dissertation], Kyiv, 342 p.

7. Novikov, S.S. (2008), “Operativnoye prognozirovaniye elektropotrebleniya metallurgicheskogo predpriyatiya kak sredstvo snizheniya rynochnykh riskov” [Rapid forecasting of electricity consumption of a metallurgical enterprise as a means of reducing market risks], MEI Bulletin, No. 1, pp. 91-97.

8. Molokanova, V. and Petrenko, V. (2016), Project-oriented approach to metallurgical enterprises sustainable development management, Metallurgical and mining industry, No. 8, pp. 28-35.

9. Bushuyev, S.D. and Bushuyeva, N.S. (2009), "Formuvannya tsinnosti v diyal'nosti proektno-oriyentovanykh orhanizatsiy" [Formation of value in the activities of project-oriented organizations], Project management and production development: science bulletin, No. 3(31), pp. 5-14.

10. Molokanova, V. M., Orliuk, O. P., Petrenko, V. O., Butnik-Syverskyi, O. B. and Khomenko, V. L. (2020), Formation of metallurgical enterprise sustainable development portfolio using the method of analyzing hierarchies, Scientific Bulletin of the National Mining University, No. 2, pp. 131-136. https://doi.org/10.33271/nvngu/2020-2/131.

11. Sukhomlin, L.V. and Orlova, K.O. (2017), Strategic Planning as a Method of Steel Development of the Metal Industry, Materials of the 5th National Science Conference "Actual Problems and Prospects for the Development of the Economy in the Thoughts of Global Instability”, pp. 143-144.

12. Linares, P. and Labandeira, X. (2010), Energy efficiency: Economics and policy, Journal of Economic Surveys. No. 24(3), pp. 573-592. https://doi.org/10.1111/j.1467-6419.2009.00609.x. 
13. Nikiforov, G.V., Oleinikov. V.K. and Zaslavets, B.I. (2003), "Ehnergosberezhenie i upravlenie ehnergopotrebleniem v metallurgicheskom proizvodstve” [Energy conservation and energy management in the metallurgical industry], Energoatomizdat, Moscow, $480 \mathrm{p}$.

14. Bianco, V., Manca, O. and Nardini, S. (2009), Electricity consumption forecasting in Italy using linear regression models, Energy, No. 34, pp. 1413-1421. https://doi.org/10.1016/j.energy.2009.06.034.

15. Dordonnat, V., Koopman, S.J. and Ooms, M. (2012), Dynamic factors in periodic time-varying regressions with an application to hourly electricity load modeling, Computational Statistics and Data Analysis, No. 56, pp. $3134-3152$. htpps://doi.org/10.1016/j.csda.2011.04.002.

16. Kazarinov, L.S., Koptsev, L.A. and Yapryntseva, I.A. (2007), “Optimal'noe prognozirovanie potrebleniya toplivnykh gazov na metallurgicheskikh predpriyatiyakh” [Optimal forecasting of fuel gas consumption at metallurgical enterprises], Bulletin of the South Ural State University. Series: Computer Technologies, Management, Electronics, No. 7(79), pp. 24-26.

17. Mosavi, A. and Bahmani, A. (2019), Energy Consumption Prediction Using Machine Learning: A Review, Preprints, available at: https://www.preprints.org/manuscript/201903.0131/v1/download (accessed 1 December 2019).

18. Manusov, V.Z., Mogilenko, A.V. and Kostromin, V.P. (2003), “Otsenka i prognozirovaniye elektropotrebleniya v energosistemakh na osnove nechetkogo regressionnogo analiza” [Assessment and forecasting of power consumption in power systems based on fuzzy regression analysis], Electricity, No. 7, pp. 41-43.

19. Yujuan, R. and Bao, H. (2016), Modeling and Simulation of Metallurgical Process Based on Hybrid Petri Net, IOP Conference Series: Materials Science and Engineering, pp. 157. https://doi.org/10.1088/1757-899X/157/1/012018.

20. Xueying, W., Zhuchao, Y., Pengfei, X., Gaixia, C., Shiyang, L., Jing, L. and Yuanzheng, Z. (2020), An Energy Consumption Prediction LSTM Model of Metallurgy Enterprises, IOP Conference Series: Earth and Environmental Science, Vol. 495, pp. 012014. https://doi.org/10.1088/1755-1315/495/1/012014.

21. Rakhmonov, I., Berdishev, A., Niyozov, N., Muratov, A. and Khaliknazarov, U. (2020), Development of a scheme for generating the predicted value of specific electricity consumption, IOP Conference Series: Materials Science and Engineering, Vol. 883, pp. 012103. https://doi.org/10.1088/1757-899X/883/1/012103.

22. Shemetov, A.N. and Oleynikov, V.K. (2014), “Adaptivnoye upravleniye rezhimami elektropotrebleniya promyshlennogo ob'yekta po kompleksnomu kriteriyu" [Adaptive control of power consumption modes of an industrial facility according to a complex criterion], Chief Power Engineer, No. 4, pp. 30-37.

23. Voronov, I.V. and Politov, E.A. (2009), "Kratkosrochnoye prognozirovaniye elektropotrebleniya energosistem s pomoshch'yu iskusstvennykh neyronnykh setey" [Short-term forecasting of power consumption of power systems using artificial neural networks], Electric stations, No. 12, pp. 15-18.

24. Shcherbakov, M.V., Nabiullin, A.S. and Kamaev, V.A. (2012), Multiagent system for modeling the production and consumption of electricity in hybrid power systems, Engineering Bulletin of the Don, Vol. 20, No. 2, pp. 217-221.

25. Kiyko, S., Druzhinin, E., Prokhorov, O. and Haidabrus, B. (2020), Multi-agent Model of Energy Consumption at the Metallurgical Enterprise, DSMIE 2020: Design, Simulation, Manufacturing: The Innovation Exchange, pp. 156-165. htpps://doi.org/10.1007/978-3-030-50794-7_16.

\section{Список літератури}

1. Koksharov V.A. Theoretical-methodological basis of formation of the enterprise strategy improving energy efficiency / V.A. Koksharov // European Science and Technology: materials of the X International research and practice conference, Publishing office Vela Verlag Waldkraiburg, Munich, Germany. - 2015. - Vol. I. - P. 143-148.

2. Anatomy of a paradox: Management practices, organizational structure and energy efficiency / R. Martin, M. Muüls, L.B. De Preux, U.J. Wagner // Journal of Environmental Economics and Management. - 2012. - No. 63(2). - P. 208-223.

3. Лизунова О.М. Механізми управління енергетичною складовою в системі забезпечення ефективності металургійних підприємств: монографія / О.М. Лизунова. - Маріуполь: ДВНЗ “ПДТУ”, 2017. - 263 с.

4. Дубровін В.І. Управління портфелями проектів енергозбереження на металургійних підприємствах / B.I. Дубровін, О.І. Юськів // Радіоелектроніка та інформатика. - 2019. - № 2(85). - С. 43-46.

5. Дубровін В.І. Структура інформаційної технології управління портфелями проектів енергозбереження на металургійних підприємствах / В.І. Дубровін, О.І. Юськів // Електротехніка та електроенергетика. - 2019. - № 4. - С. 4655.

6. Цюцюра С.В. Управління інноваційними проектами модернізації підприємств енергоємних галузей: дис. ... д-ра техн. наук: 05.13.22 / Цюцюра С.В. - К.: Київський національний ун-т будівництва і архітектури, 2007. - 342 с.

7. Новиков С.С. Оперативное прогнозирование электропотребления металлургического предприятия как средство снижения рыночных рисков / С.С. Новиков // Вестник МЭИ. - 2008. - № 1. - С. 91-97.

8. Molokanova V. Project-oriented approach to metallurgical enterprises sustainable development management / V. Molokanova, V. Petrenko // Metallurgical and mining industry. - 2016. - № 8. - P. 28-35.

9. Бушуєв С.Д. Формування цінності в діяльності проектно-орієнтованих організацій / С.Д. Бушуєв, Н.С. Бушуєва // Управління проектами та розвиток виробництва: Зб.наук.пр. - Луганськ: вид-во СНУ ім. В. Даля, 2009. - № 3(31). C. 5-14.

10. Formation of metallurgical enterprise sustainable development portfolio using the method of analyzing hierarchies / V.M. Molokanova, O.P. Orliuk, V.O. Petrenko, O.B. Butnik-Syverskyi, V.L. Khomenko // Naukovyi Visnyk Natsionalnoho Hirnychoho Universytetu. - 2020. - No. 2. - P. 131-136. https://doi.org/10.33271/nvngu/2020-2/131. 
11. Sukhomlin L.V. Strategic Planning as a Method of Steel Development of the Metal Industry / L.V. Sukhomlin, K.O. Orlova // Proc. of the 5th National Science Conference "Actual Problems and Prospects for the Development of the Economy in the Thoughts of Global Instability”. - 2017. - P. 143-144.

12. Linares P. Energy efficiency: Economics and policy / P. Linares, X. Labandeira // Journal of Economic Surveys. 2010. - No. 24(3). - P. 573-592. https://doi.org/10.1111/j.1467-6419.2009.00609.x.

13. Никифоров Г.В. Энергосбережение и управление энергопотреблением в металлургическом производстве / Г.В Никифоров, В.К. Олейников, Б.И. Заславец. - М.: Энергоатомиздат, 2003. - 480 с.

14. Bianco V. Electricity consumption forecasting in Italy using linear regression models / V. Bianco, O. Manca, S. Nardini // Energy. - 2009. - № 34. - P. 1413-1421. https://doi.org/10.1016/j.energy.2009.06.034.

15. Dordonnat V. Dynamic factors in periodic time-varying regressions with an application to hourly electricity load modeling / V. Dordonnat, S.J. Koopman, M. Ooms // Computational Statistics and Data Analysis. - 2012. - № 56. - P. 3134-3152. htpps://doi.org/10.1016/j.csda.2011.04.002.

16. Казаринов Л.С. Оптимальное прогнозирование потребления топливных газов на металлургических предприятиях / Л.С. Казаринов, Л.А. Копцев, И.А. Япрынцева // Вестник Южно-Уральского государственного университета. Серия: Компьютерные технологии, управление, радиоэлектроника. - 2007. - № 7(79). - С. 24-26.

17. Mosavi A. Energy Consumption Prediction Using Machine Learning: A Review, Preprints [Електронний ресурс] / A. Mosavi, A. Bahmani. - 2019. - Режим доступу: https://www.preprints.org/manuscript/201903.0131/v1/download.

18. Манусов В.З. Оценка и прогнозирование электропотребления в энергосистемах на основе нечеткого регрессионного анализа / В.3. Манусов, А.В. Могиленко, В.П. Костромин // Электрика. - 2003. - № 7. - С. 41-43.

19. Yujuan R. Modeling and Simulation of Metallurgical Process Based on Hybrid Petri Net / R. Yujuan, H. Bao // IOP Conference Series: Materials Science and Engineering. - 2016. - P. 157. https://doi.org/10.1088/1757-899X/157/1/012018.

20. An Energy Consumption Prediction LSTM Model of Metallurgy Enterprises / W. Xueying, Y. Zhuchao, X. Pengfei, C. Gaixia, L. Shiyang, L. Jing, Z. Yuanzheng // IOP Conference Series: Earth and Environmental Science. - 2020. - Vol. 495. P. 012014. https://doi.org/10.1088/1755-1315/495/1/012014.

21. Development of a scheme for generating the predicted value of specific electricity consumption / I. Rakhmonov, A. Berdishev, N. Niyozov, A. Muratov, U. Khaliknazarov // IOP Conference Series: Materials Science and Engineering. - 2020. - Vol. 883. - P. 012103. https://doi.org/10.1088/1757-899X/883/1/012103.

22. Шеметов А.Н. Адаптивное управление режимами электропотребления промышленного объекта по комплексному критерию / А.Н. Шеметов, В.К. Олейников // Главный энергетик. - 2014. - № 4. - С. 30-37.

23. Воронов И.В. Краткосрочное прогнозирование электропотребления энергосистем с помощью искусственных нейронных сетей / И.В. Воронов, Е.А. Политов // Электрические станции. - 2009. - № 12. - С. 15-18.

24. Shcherbakov M.V. Multiagent system for modeling the production and consumption of electricity in hybrid power systems / M.V. Shcherbakov, A.S. Nabiullin,V.A. Kamaev // Engineering Bulletin of the Don. - 2012. - Vol. 20, No. 2. P. 217-221.

25. Multi-agent Model of Energy Consumption at the Metallurgical Enterprise / S. Kiyko, E. Druzhinin, O. Prokhorov, B. Haidabrus // DSMIE 2020: Design, Simulation, Manufacturing: The Innovation Exchange. - 2020. - P. 156-165. htpps://doi.org/10.1007/978-3-030-50794-7_16.

Received by Editorial Board 19.08.2020

Signed for Printing 22.09.2020

\section{Відомості про автора:}

Кійко Сергій Генадійович

кандидат технічних наук

Голова правління ПрАТ Електрометалургійний завод

“Дніпроспецсталь” ім. А.М. Кузьміна,

Запоріжжя, Україна,

https://orcid.org/0000-0003-4676-5722

\section{Information about the author:}

\section{Sergey Kyiko}

Candidate of Technical Sciences

Chairman of the Board of PJSC Electrometallurgical plant

“Dniprospetsstal” named after A.M. Kuzmin,

Zaporozhye, Ukraine

https://orcid.org/0000-0003-4676-5722

\section{МЕТОДОЛОГІЯ ПРЕДИКТИВНОЇ АДАПТАЦІЇ ПРИ УПРАВЛІННІ ПОРТФЕЛЕМ ПРОЕКТІВ ЕНЕРГОЗБЕРЕЖЕННЯ НА МЕТАЛУРГИЙНИХ ПІДПРИЄМСТВАХ}

\section{С.Г. Кійко}

Запропоновано методологію управління портфелями проектів енергозбереження на металургійних підприємствах, яка формує парадигму предиктивної адаптації, заснованої на взаємопов'язаних адаптивних системах планування, моніторингу та управління змінами і дозволяє на основі прогнозування енергоспожсиання для складних технологічних прочесів і виробництв, а також моделювання $і$ оцінки якості паливно-енергетичного балансу, в умовах обмеженості ресурсів і ризиків здійснювати формування і відбір для реалізації проектів енергозбереження при узгодженні пріоритетів бізнес-стратегії і стратегї енергоефективності металургійного підприємства. Розроблено багаторівневу модель енергоспоживання металургійного підприємства, яка дозволяє очінити ефективність відібраних до реалізачії енергозберігаючих проектів, об'єктивно очінити частку кожного енергоресурсу в загальному потоці, визначити енергоємність окремого виробництва, цеху, всього підприємства, скорегувати стратегічний напрямок в управлінні енергоресурсами. За допомогою моделі можливе вирішення цүілого ряду завдань, серед яких оцінка раціональності та ефективності існу- 
ючої на підприємстві структури енергоспоживання, прогнозування очікуваних рівнів енерговитрат при зміні технолоziї, сортаменту і якості продукиії, $і$ порівняння різних технологій $і$ обладнання з точки зору енергоефективності, оптимальне управління потоками енергоносіїв з урахуванням зміни умов виробництва. Сформульовано основні вимоги до організації системи планування і управління портфелем проектів енергозбереження на металургійному підприємстві. Представлена структурна схема комп'ютерної системи планування і управління портфелем проектів енергозбереження на ПрАТ “Дніпроспецсталь”. Розроблена система процесів енергозбереження повинна вбудовуватися в систему проиесів підприємства, відповідати стратегічним иілям підприємства і особливостям виробничого процесу. Розглянуто впроваджену на підприємстві схему процесу планування витрат на енергоресурси.

Ключові слова: металургійне підприємство; портфель проектів енергозбереження; енергоефективність; планування витрат; енергоресурси.

\section{МЕТОДОЛОГИЯ ПРЕДИКТИВНОЙ АДАПТАЦИИ ПРИ УПРАВЛЕНИИ ПОРТФЕЛЕМ ПРОЕКТОВ ЭНЕРГОСБЕРЕЖЕНИЯ НА МЕТАЛЛУРГИЧЕСКИХ ПРЕДПРИЯТИЯХ}

\section{С.Г. Кийко}

Предложена методология управления портфелями проектов энергосбережения на металлургических предприятиях, которая формирует парадигму предиктивной адаптации, основанной на взаимосвязанных адаптивных системах планирования, мониторинга и управления изменениями и позволяет на основе прогнозирования энергопотребления для сложных технологических прочессов и производств, а также моделирования и оиенки качества топливноэнергетического баланса, в условиях ограниченности ресурсов и рисков осуществлять формирование и отбор для реализации проектов энергосбережения при согласовании приоритетов бизнес-стратегии и стратегии энергоэффективности металлургического предприятия. Разработана многоуровневая модель энергопотребления металлургического предприятия, которая позволяет оценить эффективность отобранных к реализации энергосберегающих проектов, объективно оиенить долю каждого энергоресурса в общем потоке, определить энергоемкость отдельного производства, цеха, всего предприятия, скорректировать стратегическое направление в управлении энергоресурсали. С помощью модели возможно решение целого ряда задач, среди которых оченка рачиональности и эффективности существующей на предприятии структуры энергопотребления, прогнозирование ожсдаемых уровней энергозатрат при изменении технологии, сортамента и качества продукции, и сравнение различных технологий и оборудования с точки зрения энергоэффективности, оптимальное управление потоками энергоносителей с учетом изменения условий производства. Сформулированы основные требования к организации системы планирования и управления портфелем проектов энергосбережения на металлургическом предприятии. Представлена структурная схема компьютерной системы планирования и управления портфелем проектов энергосбережения на ЧАО “Днепроспецсталь". Разработанная система проиессов энергосбережения должна встраиваться в систему прочессов предприятия, соответствовать стратегическим иелям предприятия и особенностям производственного прочесса. Рассмотрена внедренная на предприятии схема прочесса планирования затрат на энергоресурсы.

Ключевые слова: металлургическое предприятие; портфель проектов энергосбережения; энергоэффективность; планирование затрат; энергоресурсы. 